\title{
Study on the Relationship among Airport Safety Management System, Safety Knowledgy, and Safety Behaviour
}

- Case of Incheon International Airport Airside Workers -

In Kie $\mathrm{Na}^{*}$, Kwang-eui Yoo**

\section{공항안전관리시스템(SMS)과 안전지식 및 안전행동의 관계에 대한 연구 \\ - 인천공항 이동지역종사자를 중심으로 - \\ 나인기*, 유광의**}

\begin{abstract}
안전관리시스템(Safety Management system, SMS)은 국제민간항공기구(ICAO)에서 정의된 서비스제공자의 의무사항으로 우리나라의 공항 분야는 2005년 부터 구축되어 현재까지 운 영되고 있다. 항공교통량 증가에 따른 사고의 발생가능성 증가에 대응하기 위해 채택된 새 로운 체계가 SMS라는 점을 고려할 때, 공항 $\mathrm{SMS}$ 는 항공사와 조업사 등 관련 업체와 연계 되며 이동지역에서 근무하는 종사자의 행동에도 긍정적인 영향을 미칠 수 있어야 할 것이 다. 본 연구는 인천공항이 실행하고 있는 외부지향적인 SMS활동이 항공사, 조업사 등에 소 속된 이동지역 종사자의 지식과 행동에 미치는 영향에 대해 연구하고자 하였다. 총 593명의 종사자가 조사에 참여하였으며, 공항SMS는 안전지식을 통해 안전행동에 영향을 미치는 것 으로 나타났다. 이 연구 결과는 공항이 조업사 등 별개의 업체 종사자에 대한 안전정책 설 정을 위한 기초자료로 활용될 수 있을 것으로 기대된다.
\end{abstract}

Key Words : 공항안전관리시스템(Airport Safety Management System), 공항 이동지역 안전 (Airside Safety), 안전지식(Safety Knowledgy), 안전행동(Safety Behaviour), 이동지역 종사자 (Airside workers)

\section{Introduction}

The airport is an infrastructure facility that connects air and land transportation. Airport airside includes facilities for aircraft take off and landing

Received : 25. Nov. 2018. Revised : 07. Dec. 2018.

Accepted : 23. Dec. 2018

* 한국항공대학교 대학원 항공교통물류학과

** 한국항공대학교 대학원 항공교통물류학과 교수

연락저자 E-mail : keyoo@kau.ac.kr

연락저자 주소 : 10540 경기도 고양시 덕양구 항공 대학로 76 and air navigation(MOLT, 2017). This area which supports aircraft operations, contains high risk of accidents due to the many aircraft, vehicles, and people moving all the time(Lacagnina, 2007). Workers in this area are required specific training for airside safety regulation. The majority of work in the airport airside are to carry out in-flight meals, cleaning, baggage handling, etc. and it is considered to be unrelated to aircraft disasters classified into high risk groups such as aircraft crash. Although the airside events were not fatal, 
but property and operational losses are huge due the frequency. To make it worse, more air traffic may cause more accidents on space-limited airside. Flight safety foundation states that more than 27,000 airside accidents(one per 1,000 departures) occurred and injuring more than 243,000 people $(9$ per 1,000 departures) in the world(Flight Safety Foundation, 2008). They caused at least $\$ 10$ billion loss a year for major airlines. International organizations including ICAO, ACl, etc are making various efforts to develop a Ground Accident Prevention Program(GAP) to prevent accidents by joint efforts. Despite these efforts, changes in the environment, such as the increase of flights, induce more possibility of accidents. In addition, due to the nature of the airport, many different types of duties are performed at same place and same time. The causes of accidents at the airport are very diverse, which makes the prevention of accidents more difficult. Therefore, it is necessary for all relevant stake holders' efforts to prevent accidents. It is indicated that the safety management system of aerodrome operators should include the safety organization, responsibility and obligation, safety policy and management procedures required for its own safety management in accordance with the state safety program(MOLT, 2017). The items set as safety objectives for korean airport operators consist mainly of (5 out of 6) aircraft-related accidents and incidents that can be exposed to operators within the airside. It is shown in Table 1.

Airport SMS is required to operate for apron and aircraft safety in the airside area. The purpose of this study is to analyze the safety knowledge by airport SMS on the safety behavior of the worker belonging to separate company rather than the airport. Additionally, in order to identify practical meaning for airport safety in the nationwide, identifying the SMS strategy and its components where positively and efficiently affect airside workers' safety will follow.
Table 1. Korean Airport Safety Objectives

\begin{tabular}{|c|c|c|}
\hline Category & Definition & $\begin{array}{l}\text { Relationship } \\
\text { with airside } \\
\text { workers }\end{array}$ \\
\hline \multirow{2}{*}{$\begin{array}{l}\text { Ground } \\
\text { traffic } \\
\text { accident }\end{array}$} & $\begin{array}{l}\text { 1. Collision between standing } \\
\text { aircraft or vehicle / equipment } \\
\text { and any subject. }\end{array}$ & Yes \\
\hline & $\begin{array}{l}\text { 2. Damages(death, aircraft, } \\
\text { facility, vehicle, etc) occurred } \\
\text { by collision of human or } \\
\text { vehicle's unintended action. }\end{array}$ & Yes \\
\hline \multirow{4}{*}{$\begin{array}{l}\text { Aerodrome } \\
\text { malfunc- } \\
\text { tioning }\end{array}$} & $\begin{array}{l}\text { 3. Fire in movement area which } \\
\text { can negatively affect on } \\
\text { aircraft operation }\end{array}$ & Yes \\
\hline & $\begin{array}{l}\text { 4. Foreign Objective Debris / } \\
\text { Damage(FOD) discovered } \\
\text { in movement area and it } \\
\text { can negatively affect on } \\
\text { aircraft operation }\end{array}$ & Yes \\
\hline & $\begin{array}{l}\text { 5. Fuel leak which can causes } \\
\text { delay on aircraft operation }\end{array}$ & Yes \\
\hline & 6. Apron lighting system failure & No \\
\hline
\end{tabular}

\section{Main subject}

\subsection{Theoretical background}

ICAO defines the SMS as a system that can ensure safe operation through effective risk management(ICAO, 2013). The countries with ICAO agreement shall establish State Safety Program(SSP), and their international service providers, including airports and airline, are required to operate SMS. South Korean airport operators - Incheon International Airport Corporation(IIAC) and Korea Airport Corporation(KAC) - defines that SMS is a management procedure includes organization, policy, accountability and obligation to carry out airport safety management in accordance with the state safety program(IIAC, 2018). International organizations and many CAAs distinguish four components of SMS : safety policy and objectives, risk management, safety assurance, and safety promotion. Safety policies 
are the official expression of the organization's investment in principles, regulations and safety on safety issues(Cooper, Philips, 2004). The Federal Aviation Administration(2006) has obliged to US air service providers to establish policies and procedures and organizational structures in their SMS. Risk management is a process to assess the level of exposure to risks in the current operating environment (Kim, Sin, 2011) and mitigation strategy to reduce risk must be ALARP(As Low As Reasonably Praticable). Safety assurance process is a performance monitoring procedure that can confirm whether the safety policy and goals are achieved (Park, 2014). It can also continuously monitor or measure safety activities, including identified hazards (FAA, 2006), and collected reports (voluntary / mandatory). Safety promotion is an activity that fosters a positive safety culture and environment by encouraging safety attitudes and actions (ICAO, 2013). ICAO Doc(Document) 9859 has stated training and communication are the main items in the promotion of safety. In addition to activities indicated from ICAO Doc 9859, South Korean airport operators have conducted activities such as FOD campaigns, training, and bulletins that share information that airport airside workers should be aware of. In this study, the operational definition of the safety management system is safety activities that affect airport stakeholders' safety and limited in airside operation. Kallgren \& Wood (1986) conclude that safety knowledge plays a positive role in matching individual attitude and external behaviors. Sherehiy \& Kawowski (2006) distinguishes safety knowledge in two types explicit knowledge and tacit knowledge. Explicit knowledge is easy to share knowledge with an organization in which many individuals can be documented. on the other hand, tacit knowledge is an individual experience depending on the situation, and it is difficult share with others. Chang \& Liao(2009) reported that safety knowledge, documented and learned by workers, had a positive effect on attitudes, which can be seen as explicit knowledge. On the other hand, Håvold(2010) measured the tacit knowledge used as a measure to distinguish office workers from field workers through his research evaluating his own safety knowledge and experience. Carrillo \& Chinowsky(2006) stressed the importance of field knowledge because effective knowledge management encouraging ideas exchange appeared as productivity, customer service, and staff settlement. Hofmann, Jacobs \& Landy(1995) defined that safety knowledge is the acquisition of regulatory procedures, as an understanding of the safety operating procedures and the appropriate training and instruction personnel. In this study, safety knowledge is defined from previous studies plus knowledge from training related to the field and regulations shared from the company and the airport safety management system. Safety behavior is the activities of protecting individuals from harm by adding safety knowledge and skills needed for the way they do their work safely (Gressgård, Hansen, 2015). Safety behavior has been categorized into two types: complying with mandatory requirements (safety compliance) and being actively (safety participation) involved in many previous studies. Jiang \& Probst(2016) defined safety compliance as an action that requires an immediate situation in relation to safety (eg. wearing a safety guard before work). Gressgard(2015) stressed that safety compliance is a key component of safety behavior. Safety participation, on the other hand, is a more than passive action that goes a step further from regulatory compliance, meaning that it has an active role (eg, volutary reports). In this study, 
the operational definition of safety behavior is 'active or passive behavior that contributes to prevent accidents by airside workers'. Based on previous studies and operational definition, we analyze the effect of safety management system airside workers deployed at airports on safety knowledge and safety behavior.

\subsection{Research model}

The purpose of this study was to investigate the effect of safety management system operated by airport operator on the safety behavior of external stakeholder's employees with safety knowledge as a parameter. In order to accomplish these research objectives, following research model is presented as shown in Figure 1.

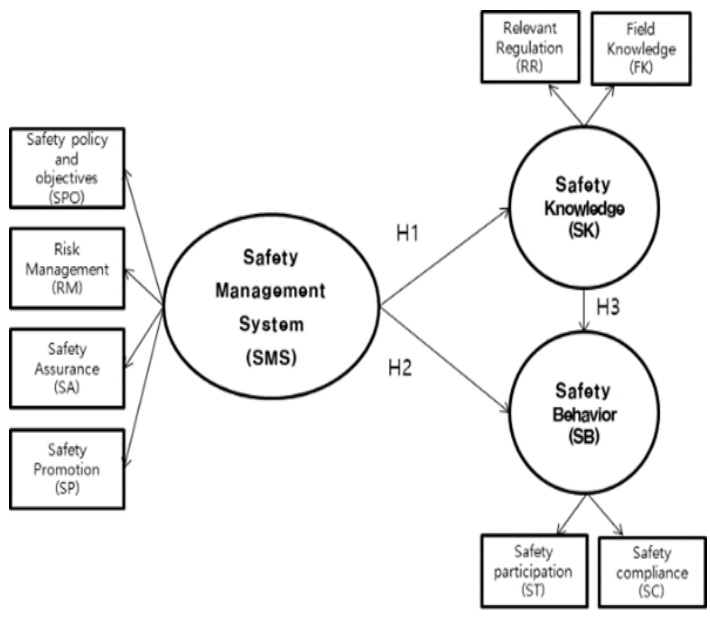

Fig 1. Research Model

\subsection{Hypothesis}

Based on the empirical research model presented above, this study sets up a research hypothesis as follows. Tam et al.(2001) reported that a change in the attitude of construction workers after introducing a new safety management system resulted in a change in the safety system that affected the cognitive response and public behavior change through attitude. Vinodkumar \& Bhasi(2010) conducted a survey of 1,566 workers about safetyorganized work practices on the safety behavior. The result show that safety knowledge and motivation were core mediators to safety behaviour. This safety management practice is specifically concerned with safety management factors such as safety regulations, procedures, training, and communication that can predict safety knowledge. Therefore, the following hypotheses can be advanced for this study based on the above-mentioned previous researches in Korea and abroad.

H1. The safety management system will positively affect safety knowledge.

Chen \& Chen(2014) found that variables including perceived SMS practices, morality leadership and self efficacy have a significant impact on the safety behavior of pilots. Cho at el.(2014) also found that airline safety management systems had a positive effect on safety behaviors such as compliance with safety rules and safety awareness through individuals' motivation. Kim(2015) pointed that the components of the safety management system had a significant effect on the safety behavior. Moreover, Vinodkumar \& Bhasi(2010) also found that the safety management system, including management participation, safety regulations and procedures contributed workers' safety compliance and participation Cho(2015) analyzed the systemic factors to safety behaviour performance, and the result was that invisible factors (interests, mood, training results etc) in systemic factor have an important influence on safety behaviour. Previous research in other industry than aviation shows that the human resource management system, similar to aviation safety management system, has an effect on organizational behavior and creative behavior 
(Jang, 2015). In the study of Moon(2013) certain sub-factors of performance management system have effects on the behaviors such as job satisfaction.

H2. The safety management system will positively affect safety behavior.

Studies that safety knowledge affects on safety behavior have been conducted early in other areas. Neal. et al(2000). conducted a survey of 525 Australian workers divided into 32 groups, which suggested that safety knowledge positively affects compliance and participation that constitute safety behavior. Chang \& Liao(2009) analyzed the safety behaviors of 288 passengers who received safety training from the crew after boarding the aircraft. The result was that safety knowledge acquired through crew's practice positively influenced safety behaviors including the safety attitude of passengers. Chen \& Chen(2014) surveyed 239 pilots and found that the components of SMS directly affected the safety behavior, and Watcher \& Yorio(2013) argued that perceived SMS directly affects on safety behaviour and accident reduction.

H3. Safety knowledge will positively affect safety behavior.

\subsection{Instrument and measure}

The questionnaires used in this study were prepared based on the previous literature research, and the questionnaires were supplemented and revised. The questionnaire consists of demographic characteristics and safety management system, safety knowledge, and safety behavior. The scale on the questionnaire was composed of 5 points of Likert scale, 5 points of 'strongly agree' and 1 point of 'not at all'. The paper based survey was conducted from June 12, 2017 to October 14,
2017, for airlines, ground handlers, and contractor companies in Incheon international airport. A total of 650 questionnaires were distributed, of which 612 were collected. Of the samples, 57 were used in the final analysis, except for the analysis of 57 questions that were insufficient or inadequate.

\subsection{Data analysis}

In order to verify the hypothesis of this study, the collected data based on the questionnaires were analyzed using SPSS 21.0 program and AMOS 20.0 package program. First, frequency analysis was conducted to examine the demographic characteristics of the respondents. Second, factor analysis was conducted to verify the validity of the measurement tools. Cronbach's Alpha value was calculated through reliability analysis to verify the internal consistency between variables. Third, the research hypothesis was verified using Structural Equation Modeling (SEM) to identify Confirmatory Factor Analysis(CFA) and path coefficients of structural models.

\subsection{Empirical Analysis}

\subsubsection{Population}

In order to analyze the characteristics of respondents, frequency analysis was conducted on demographic characteristics and general characteristics. There were 540 (91.1\%) males and 53 females $(8.9 \%)$ in the gender distribution of airside workers. By age, 193(32.5\%) were in their 30s, 171 (28.8\%) were in their 40s, followed by $66(11.1 \%)$ for 20s, 50s were $133(22.4 \%)$ and 60 s were 30 (5.1). The reason of relatively small portion in $20 \mathrm{~s}$ is attributed to the frequent move for job due to their physical hardship and low wages. 
Table 2. Population

\begin{tabular}{|c|c|c|c|}
\hline Category 1 & Category 2 & Population & Portion(\%) \\
\hline \multirow{2}{*}{ Gender } & Male & 540 & 91.1 \\
\hline & Female & 53 & 8.9 \\
\hline \multirow{5}{*}{ Age } & $20 \mathrm{~s}$ & 66 & 11.1 \\
\hline & 30s & 193 & 32.5 \\
\hline & $40 \mathrm{~s}$ & 171 & 28.8 \\
\hline & $50 \mathrm{~s}$ & 133 & 22.4 \\
\hline & 60 s or over & 30 & 5.1 \\
\hline \multicolumn{2}{|c|}{ Total } & 593 & 100.0 \\
\hline
\end{tabular}

\subsubsection{General characteristics}

593 employees in safety and operational departments who could be related to airport accidents directly or indirectly. 438 workers in ground handling (73.9\%) answered that they had the largest number of respondents, 83 from airport contractors $(14 \%)$ and 72 from airlines $(12.1 \%)$. The survey was intended to ground handling workers mainly related to the airport safety management system. 51(71\%) of airlines(72) was answered that their duties have a direct impact on safety such as maintenance, safety management, and flight service support. 61 out of 82 employees in airport maintenance contractors responded their duty related airport safety. Considering that survey was conducted to departments related to airport safety, there are certain portion of respondents those did not aware that his work is related to safety. $17.3 \%$ $(29.9 \%)$ of respondents had between 1 to 5 years of job experience and 132 (22.3\%) of respondents answered between 5 to 10 years of job experience. therefore less than 10 year experienced employees occupied largest portion(51.4\%) of respondent working related to airport safety.
Table 3. General Characteristics

\begin{tabular}{|c|c|c|c|c|}
\hline \multicolumn{2}{|c|}{ Types 1} & Types2 & $\begin{array}{l}\text { Popul- } \\
\text { ation }\end{array}$ & portion \\
\hline \multirow{3}{*}{\multicolumn{2}{|c|}{ Company }} & Airline & 72 & 12.1 \\
\hline & & Ground andler & 438 & 73.9 \\
\hline & & $\begin{array}{c}\text { Airport } \\
\text { contractor }\end{array}$ & 83 & 14.0 \\
\hline \multirow{9}{*}{$\begin{array}{l}\text { Com } \\
\text { pany } \\
\text { types }\end{array}$} & \multirow{4}{*}{ Airline } & Engineering & 19 & 26.4 \\
\hline & & Service & 23 & 31.9 \\
\hline & & Safety mgmt & 9 & 12.5 \\
\hline & & etc & 21 & 29.2 \\
\hline & \multirow{3}{*}{$\begin{array}{l}\text { Ground } \\
\text { Handler }\end{array}$} & Driving & 118 & 26.9 \\
\hline & & Ground upport & 237 & 54.1 \\
\hline & & etc & 83 & 18.9 \\
\hline & \multirow{2}{*}{$\begin{array}{l}\text { Airport } \\
\text { contractor }\end{array}$} & $\begin{array}{c}\text { Facility } \\
\text { maintanance }\end{array}$ & 61 & 74.4 \\
\hline & & etc & 21 & 25.6 \\
\hline \multirow{6}{*}{\multicolumn{2}{|c|}{$\begin{array}{c}\text { Work } \\
\text { Experience }\end{array}$}} & Less than 1 year & 79 & 13.3 \\
\hline & & $1 \sim 5$ & 173 & 29.2 \\
\hline & & $5^{\sim 10}$ & 132 & 22.3 \\
\hline & & $10^{\sim 15}$ & 78 & 13.2 \\
\hline & & $15^{\sim 20}$ & 52 & 8.8 \\
\hline & & 20 & 79 & 13.3 \\
\hline \multirow{3}{*}{\multicolumn{2}{|c|}{$\begin{array}{l}\text { Training } \\
\text { Experience }\end{array}$}} & Yes & 502 & 84.7 \\
\hline & & No & 91 & 15.3 \\
\hline & & Total & 593 & 100.0 \\
\hline
\end{tabular}

\subsubsection{Confirmatory Factor Analysis}

Before the research hypothesis was verified, validation was verified by confirmatory factor analysis in this study. The results shows that, the standardized regression coefficient of each measurement variable was 0.7 or more and the SMC (Squared Multiple Correlations) was 0.4 or more. 
Table 4. Confirmatory Factor Analysis(SMS)

\begin{tabular}{|c|c|c|c|c|c|}
\hline $\begin{array}{c}\text { Construct } \\
\text { concept }\end{array}$ & $\begin{array}{c}\text { Measur } \\
\text { ement } \\
\text { variables }\end{array}$ & SMC & $\begin{array}{l}\text { Regression } \\
\text { coefficient }\end{array}$ & $\begin{array}{c}\text { Standardiz } \\
\text { ed } \\
\text { regression } \\
\text { coefficient }\end{array}$ & $a$ \\
\hline \multirow{7}{*}{$\begin{array}{c}\text { Safety } \\
\text { policy and } \\
\text { objectives }\end{array}$} & SP7 & 0.690 & 1.000(Fix) & 0.83 & \multirow{7}{*}{0.929} \\
\hline & SP6 & 0.728 & 0.928(27.061) & 0.853 & \\
\hline & SP5 & 0.667 & 0.805(23.957) & 0.816 & \\
\hline & SP4 & 0.661 & $0.756(21.742)$ & 0.813 & \\
\hline & SP3 & 0.604 & 0.756(19.053) & 0.777 & \\
\hline & SP2 & 0.691 & $0.886(24.593)$ & 0.831 & \\
\hline & SP1 & 0.598 & $0.866(22.082)$ & 0.774 & \\
\hline \multirow{4}{*}{$\begin{array}{c}\text { Risk } \\
\text { management }\end{array}$} & RM4 & 0.792 & 1.000(Fix) & 0.89 & \multirow{4}{*}{0.947} \\
\hline & RM3 & 0.827 & $1.09(34.488)$ & 0.91 & \\
\hline & $\mathrm{RM} 2$ & 0.837 & 1.107(34.963) & 0.915 & \\
\hline & RM1 & 0.824 & $1.142(34.32)$ & 0.908 & \\
\hline \multirow{7}{*}{$\begin{array}{c}\text { Safety } \\
\text { assurance }\end{array}$} & SA7 & 0.763 & 1.000(Fix) & 0.874 & \multirow{7}{*}{0.937} \\
\hline & SA6 & 0.593 & $0.896(27.38)$ & 0.77 & \\
\hline & SA5 & 0.726 & $0.933(28.531)$ & 0.852 & \\
\hline & SA4 & 0.910 & $0.936(27.881)$ & 0.843 & \\
\hline & SA3 & 0.707 & 0.879(27.806) & 0.841 & \\
\hline & SA2 & 0,582 & $0.792(21.784)$ & 0.763 & \\
\hline & SA1 & 0.641 & $0.851(25.393)$ & 0.801 & \\
\hline \multirow{10}{*}{$\begin{array}{c}\text { Safety } \\
\text { promotion }\end{array}$} & SP8 & 0.720 & 1.000 (Fix) & 0.849 & \multirow{10}{*}{0.954} \\
\hline & SP6 & 0.734 & $1.039(27.378)$ & 0.857 & \\
\hline & SP5 & 0.700 & $1.068(26.238)$ & 0.837 & \\
\hline & SP4 & 0.757 & $1.044(28.146)$ & 0.87 & \\
\hline & SP3 & 0.664 & $0.94(24.947)$ & 0.815 & \\
\hline & SP2 & 0.606 & $0.906(23.273)$ & 0.779 & \\
\hline & SP1 & 0.427 & $0.719(18.262)$ & 0.654 & \\
\hline & SP7 & 0.801 & $1.117(29.584)$ & 0.895 & \\
\hline & SP9 & 0.740 & $1.034(32.515)$ & 0.860 & \\
\hline & SP10 & 0.635 & $1.063(24.200)$ & 0.797 & \\
\hline
\end{tabular}

$a=$ Cronbach' $^{\prime}$
The result of confirmatory factor analysis show that GFI 0.844, AGFI 0.805, RMR 0.042, CFI 0.937, TLI 0.927, NFI 0.920 and RMSEA 0.077. The GFI did not appear to be above the acceptance level of 0.9 , however, the remaining indices fit the acceptance level, which is totally satisfactory. As a result of calculation for each latent variable in the measurement model, the AVE value of all constituent concepts is 0.5 or more and the conceptual confidence value is 0.6 or more. There is intensive validity among the measurement variables used in this study.

Table 5. Evaluation of discriminant validity (Safety Management System)

\begin{tabular}{|c|c|c|c|c|c|c|}
\hline & SPO & RM & SA & SP & AVE & $\begin{array}{c}\text { Conceptual } \\
\text { reliability }\end{array}$ \\
\hline SPO & 1 & & & & 0.680 & 0.680 \\
\hline RM & 0.448 & 1 & & & 0.840 & 0.840 \\
\hline SA & 0.487 & 0.376 & 1 & & 0.702 & 0.702 \\
\hline SP & 0.296 & 0.227 & 0.389 & 1 & 0.695 & 0.700 \\
\hline
\end{tabular}

Discriminant Validity is compared with the intensive validity by determining whether there is a difference between the construct concepts, and it is verified by comparing the average variance extracted with the square of the correlation coefficient of each factor. The criterion for discriminant validity is satisfied if each variance extracted index (AVE) is greater than the squared correlation coefficient (Fornell and Larcker, 1981). The results of Average Variance Extracted(AVE) of each construction concept are shown in Tables 4 and 6 . 
Table 6. Confirmatory Factor Analysis(Safety Knowledge, Safety Behavior)

\begin{tabular}{|c|c|c|c|c|c|c|}
\hline \begin{tabular}{c|} 
Cons \\
truct \\
conc \\
ept
\end{tabular} & \multicolumn{2}{|c|}{$\begin{array}{l}\text { Measurement } \\
\text { variable }\end{array}$} & SMC & $\begin{array}{l}\text { Regression } \\
\text { coefficient }\end{array}$ & $\begin{array}{c}\text { Standardiz } \\
\text { ed } \\
\text { regression } \\
\text { coefficient }\end{array}$ & $a$ \\
\hline \multirow{14}{*}{ SK } & \multirow{7}{*}{$R R$} & Regulation1 & 0.528 & 1.000 (Fix) & 0.727 & \multirow{7}{*}{0.93} \\
\hline & & Regulation2 & 0.603 & $1.055(27.61)$ & 0.776 & \\
\hline & & Regulation3 & 0.694 & $1.346(20.082)$ & 0.833 & \\
\hline & & Regulation4 & 0.717 & $1.37(20.358)$ & 0.847 & \\
\hline & & Regulation5 & 0.709 & $1.421(18.5)$ & 0.842 & \\
\hline & & Regulation6 & 0.693 & $1.257(20.07)$ & 0.832 & \\
\hline & & Regulation7 & 0.692 & $1.364(20.129)$ & 0.832 & \\
\hline & \multirow{7}{*}{ FK } & Field1 & 0.558 & 1.000 (Fix) & 0.747 & \multirow{7}{*}{0.92} \\
\hline & & Field2 & 0.601 & $1.071(21.225)$ & 0.775 & \\
\hline & & Field3 & 0.631 & $1.132(19.873)$ & 0.794 & \\
\hline & & Field4 & 0.631 & $1.173(19.888)$ & 0.794 & \\
\hline & & Field5 & 0.715 & $1.219(21.329)$ & 0.846 & \\
\hline & & Field6 & 0.614 & $1.196(19.45)$ & 0.784 & \\
\hline & & Field7 & 0.568 & $1.265(18.774)$ & 0.753 & \\
\hline \multirow{13}{*}{ SB } & \multirow{7}{*}{ ST } & participation1 & 0.479 & 1.000 (Fix) & 0.692 & \multirow{7}{*}{0.924} \\
\hline & & participation2 & 0.629 & $1.097(22.891)$ & 0.793 & \\
\hline & & participation3 & 0.627 & $1.055(17.936)$ & 0.792 & \\
\hline & & participation4 & 0.711 & $1.21(18.977)$ & 0.843 & \\
\hline & & participation5 & 0.773 & $1.289(19.688)$ & 0.879 & \\
\hline & & participation6 & 0.533 & $1.168(16.614)$ & 0.73 & \\
\hline & & participation7 & 0.617 & $1.234(17.797)$ & 0.786 & \\
\hline & \multirow{6}{*}{ SC } & compliance1 & 0.696 & 1.000 (Fix) & 0.834 & \multirow{6}{*}{0.931} \\
\hline & & compliance2 & 0.786 & $1.031(27.864)$ & 0.886 & \\
\hline & & compliance3 & 0.798 & $1.037(28.18)$ & 0.893 & \\
\hline & & compliance4 & 0.804 & $1.055(28.312)$ & 0.897 & \\
\hline & & compliance5 & 0.665 & $0.945(24.107)$ & 0.815 & \\
\hline & & compliance6 & 0.488 & $0.964(19.409)$ & 0.698 & \\
\hline
\end{tabular}

Table 7. Safety Knowledge and Safety Behavior Confirmatory factor analysis showed that GFI 0.833, AGFI 0.788, RMR 0.048, CFI 0.928, TLI 0.915, NFI 0.911, and RMSEA 0.079. The GFI did not appear to be above the acceptance level of 0.9 , but the remaining indices fit the acceptance level, In addition, the AVE value of all constructs is 0.5 or more in the measurement model, and there is intensive validity among the measurement variables used in this study.
Table 7. Discriminant Validity Analysis(Safety Knowledge, Safety Behavior)

\begin{tabular}{|c|c|c|c|c|c|c|}
\hline & FK & RR & ST & SC & AVE & $\begin{array}{c}\text { Conceptu } \\
\text { al } \\
\text { reliability }\end{array}$ \\
\hline FK & 1 & & & & 0.678 & 0.678 \\
\hline RR & 0.103 & 1 & & & 0.701 & 0.701 \\
\hline ST & 0.084 & 0.072 & 1 & & 0.660 & 0.660 \\
\hline SC & 0.109 & 0.081 & 0.135 & 1 & 0.749 & 0.750 \\
\hline
\end{tabular}

\subsubsection{Results}

To verify the hypothesis of this study, structural equation model analysis was conducted. As a result of the analysis, the fitness index of the model satisfies the acceptance level of fitness by $\chi^{2}=83.879, \mathrm{df}=13, \mathrm{p}<0.001$, GFI $=0.964, \mathrm{AGFI}=0.900, \mathrm{RMR}=0.018, \mathrm{CFI}=0.986$, TLI $=0.969$ and RMSEA $=0.096$. Therefore, the structural model was an acceptable level(Hum Bentler, 1999). The results of hypothesis testing are shown in Figure 2.

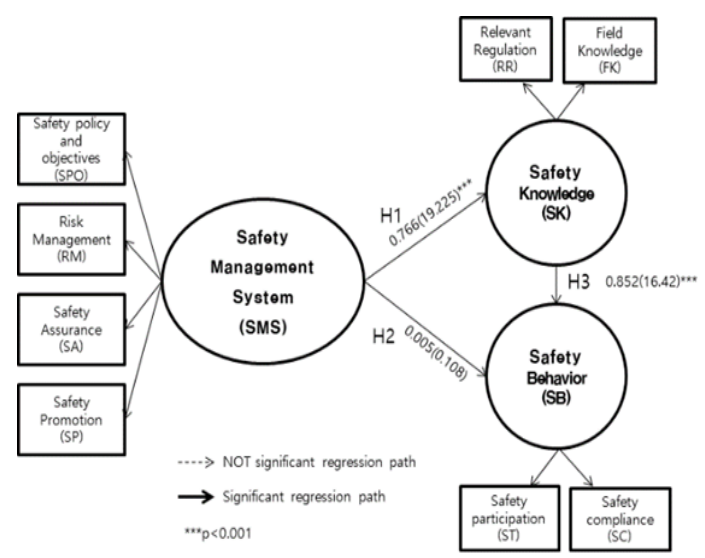

Fig 2. Analysis of Research Model

The effect of the airport safety management system on safety knowledge was statistically significant with $\beta=0.766$ and C.R. $=19.225(\mathrm{p}$ $<0.001$ ), so H1 and H were adopted. On the other hand, the safety management system showed that safety behavior was not significant when $\beta$ 
$=0.005$ and C.R. $=0.108$. The hypothesis that the knowledge of safety affects safety behavior is $\beta$ $=0.852$ and C.R. $=16.42$, which is statistically significant.

The hypotheses $\mathrm{H} 1$ and $\mathrm{H} 3$ were adopted and the hypothesis $\mathrm{H} 2$ was rejected.

\section{Conclusion}

The purpose of this study is to investigate the effect of airport safety management system on the safety behaviors of airside workers through their safety knowledge. The study was conducted on 593 workers in the airport movement area. While studies on the safety of an aircraft and airline have been conducted as major portion in air safety area, this study has academic meaning that there is no research on airside workers and related to the safety management system being implemented as international standards so far. In addition, practical implication can be discovered where policy and implementation plan development to upgrade the methodology protecting the assets such as the airside workers and the aircraft. As a result of the empirical analysis, first, the major activities of the safety management system deployed by airport authority were found to have a significant influence on the safety knowledge of workers. Second, the safety management system implemented by airport authority did not directly affect the safety behaviors of airside workers. Third, safety knowledge of workers has a significant effect on safety behavior. The results of this hypothesis are consistent with those of the previous studies. Although the airport safety management system does not directly affect safety behaviors of migrant workers, it does affect safety behaviors. Therefore, in order to develop the safety behaviors of the airside workers, the safety management system should prepare countermeasures to improve in the safety knowledge.

\section{Declarations}

Funding

: There has been no financial support for this work that could have influenced its outcome.

Acknowledgement

: This article was presented in KSAA 25th Anniversary and Fall Academic Conference in 2018, and modified to publish for an academic journal.

\section{References}

[1] National Law information center "Aviation Act" Sejong-si 30102, ROK, 2017 [cited 2018 Feb 5]; [Available from: .

http://www.law.go.kr/법령 / 공항시설법/. Accessed Feb 2018]

[2] Lacagnina, M., "Difusing the ramp", Aerosafety world, 2(5), 2007, pp.20-24

[3] Flight Safety Foundation "Ground Accident Prevention(GAP)", 2018 [Available from: https://flightsafety.org/toolkits-resources/p ast-safety-initiatives/ground-accident-prevent ion-gap/]

[4] National Law information center "Aviation Act" 2017 [cited 2018 Feb 5]; [Available from: . http://www.law.go.kr/국가항공안전프로그 램/. Accessed Feb 2018]

[5] ICAO, "Safety Management Document (DOC9859)", Montreal, 2013, pp.xii, 4-9

[6] Incheon international airport corpoation, "Safety Management Manual", Incheon, 2018. pp.2

[7] Cooper, M.D., Phillips, R.A., "Exploratory analysis of the safety climate and safety behavior relationship", Journal of Safety Research, 35, 2004, pp.497-412.

[8] FAA "FAA AC 120-92", Washington, 2006, pp. 9 
[9] Kim DH, Sin DJ, "A Comparative Study of 'Risk Frequency Criteria' on Safety Management System of Airports", Aviation Management Society of Korea9(1), 2011, pp.27

[10] Park JK, "A Study on Just Culture in Aviation Safety, Management Field", 석사 학위, Korea Aerospace Unversity, Seoul, 2014 Feb

[12] Kallgren, C.A., Wood, W., "Access to attitude-relevant information in memory as a determinant of attitude - behavior consistency". Journal of Experimental Social Psychology 22, 1986, pp.328 - .338

[13] Sherehiy, B., and Karwowski, W. "KM for occupational safety, health and ergonomics", Human Factors Ergon. Manuf. Serv. Ind.,16(3), 2006, pp.309 - H319

[14] Chang, Y., \& Liao, M.. "The effect of aviation safety education on passenger cabin safety awareness", Safety Science,47(10), 2009, pp.1337-1345.

[15] Håvold, J. I.. "Safety culture and safety management aboard tankers", Reliability Engineering and System Safety, 95(5), 2010, pp.511-519.

[16] Carrillo, P., and Chinowsky, P. "QExploiting KM: The engineering and construction perspective."J. Manage. Eng., 22(1), 2006, pp. 2 - 10.

[17] Hofmann, D. A., Jacobs, R., \& Landy, F, High reliability process industries: Individual, micro, and macro organizational influences on safety performance. Journal of Safety Research, 26(3), 1995, pp.131 - 149.

[18] Gressgård, L. J., \& Hansen, K.. "Knowledge exchange and learning from failures in distributed environments: The role of contractor relationship management and work characteristics", Reliability Engineering \& System Safety, 133, 2015, pp.168

[19] Jiang L, Probst TM, “Transformational and passive leadership as cross-level moderators of the relationships between safety knowledge, safety motivation, and safety participation". Journal of safety research, 57, 2016, pp.27-32

[20] Tam, C. M., Fung, I. W. H., \& Chan, A. P. C, "Study of attitude changes in people after the implementation of a new safety management system: The supervision plan", Construction Management and Economics, 19(4), 2001, pp.393-403.

[21] Vinodkumar, M. N., \& Bhasi, M., "Safety management practices and safety behaviour: Assessing the mediating role of safety knowledge and motivation", Accident Analysis and Prevention, 42(6), 2010, pp.2082-2093.

[22] Chen, C., \& Chen, S., "Measuring the effects of safety management system practices, morality leadership and self-efficacy on pilots' safety behaviors: Safety motivation as a mediator", 2014, pp.376-385

[23] Cho SH, Kim KW, Park SS, "An Analysis on the Cockpit Crews Perception on Airlines Safety Management System and their Safety Behavior" Journal of the Korean Society for Aviation and Aeronautics 22(2), 2014, pp60-70.

[24] Kim GH, "The Effect of Airlines Safety Management System on Safety Perception and Safety Behavior", Ph.D, Kyonggi Unversity, Seoul, 2015 Dec

[25] Cho JR, "The Effect of Organizational Safety Management's System Factors on Safety Performance: Focusing on Workers' Safety Perception Focusing on Workers' Safety Perception", Ph.D, Inha University, . Incheon, 2015 Feb

[26] Jang JH, "The Effects of High Commitment HRM System on OCB and Creative Behavior at Korean firms operating in China : The Mediation Effect of the identity", M.D, Hoseo University, Cheonan, 2015 Jun

[27] Moon SB, "The Role of justice, job stress, and 
organizational citizenship behaviour in the Relation between strategic performance measurement systems and managerial performance", M.D, Busan: Donga University; 2012 Dec

[28] Neal, A., Griffin, M. A., \& Hart, P. M., "The impact of organizational climate on safety climate and individual behavior", Safety Science, 34(1), 2000, pp.99-109.

[29] Watcher J. K., Yorio P. L. “A System of Safety Management Practices and Worker Engagement for Reducing and Preventing Accidents: An Empirical and Theoretical Investigation", Accident Analysis and Prevention (7), 2013, pp.157-163

[30] Hu. L. T, \& Bentler. P. M., "Cutoff criteria for fit indexes in covariance structure analysis: Conventional criteria versus new alternatives", Structural equation modeling: a multidisciplinary journal, 6(1), pp. 1-55, 1999. 